\title{
Problem-Solving Laboratory-Based Course Development to Improve Mental Model and Mental- Modeling Ability
}

\author{
Supriyatman \\ Mathematics and Science Education Department \\ FKIP Universitas Tadulako \\ Palu, Indonesia \\ spymfis.untad@gmail.com \\ Andi Suhandi \\ Physics Department \\ FPMIPA Universitas Pendidikan Indonesi \\ Bandung, Indonesia \\ Dadi Rusdiana \\ Physics Department \\ FPMIPA Universitas Pendidikan Indonesi \\ Bandung, Indonesia
}

\author{
A. Samsudin \\ Physics Department \\ FPMIPA Universitas Pendidikan Indonesi \\ Bandung, Indonesia \\ F. C. Wibowo \\ Physics Department \\ FKIP Universitas Ageng Tirtayasa \\ Serang, Indonesia
}

\begin{abstract}
One of the factors that cause a low level of the mental model (MM) and mental-modeling ability (MMA) of students who are physics teacher candidates in one of the LPTK in Palu-Indonesia is the traditional course program. The students are unable to use their knowledge to solve the problems. Therefore, it is necessary to develop problem-solving experimentbased course program to improve physics teacher candidate's mental model (MM) and mental-modeling ability (MMA). The development of this course program uses $R \& D$ (research and development) method. This developmental process produced course program manuals consist of problem-solving-based course model, LKM (students' worksheet), PD (lecturer guide), and assessment which focuses on improving physics teacher candidate's MM and MMA. The manuals have been verified in electronic and magnetic course material.
\end{abstract}

Keywords-Mental model (MM), Mental-modeling ability (MMA), Course program, and problem-solving laboratory

\section{INTRODUCTION}

Mental model and mental-modeling ability are two important factors in the problem-solving process [1], [2]. Ref. [2] stated that someone with higher academic level will have a better mental level and higher ability in solving the problems. It means that someone's mental model is dynamic; it may improve in line with the increase of learning experiences [3] and depend on context [4]. A good mental model is constructed by linking the description of problems and the framework of knowledge [2]. In understanding how the system works, an individual needs to organize a mental model of that system in his mind by constructing a network of related concepts and understanding the functional relation between aspects and the different level of that system based on his knowledge and daily experience [5]. Ref. [6] divide the mental model into three levels:

Level 1: model as a toy or a copy of reality. The model created in this level is not based on the concept and just rely on experience that cannot explain the problem.

Level 2: a model that can guide to objective explicitly and specifically. The model made at this level is based on the concept and existing phenomena (context) of the problem but it cannot be developed.

Level 3: a constructive model to develop and examine an idea and it can be manipulated and operated in the test. The model at this level is dynamic, constructed based on the concept, context and can be developed to solve existing problems with several alternative solutions.

The ability to use and change mental model when it cannot be used or irrelevant in problem-solving process is called as the mental-modeling ability (MMA). According to [1], high mental-modeling ability (H-MMA) is indicated by producing a mental model in the form of diagram representation or other relevant representations. The mental model produced can be reconstructed, manipulated and adjusted based on the problem proportion or condition. It can rearrange its approach towards problems and keep monitoring the process of explaining and constructing its mental model, checking the mental model and answering relative new problems by using an alternative approach. 
It is undeniable that the final goal of physics learning process is problem-solving ability $[7,8,9]$. The category shift from novice to expert problem solver requires the improvement of problem-solving ability [10]. The research result of Ref. [11] that test physics education students in one of a state university in Central Sulawesi in their second and fourth semester when took Fundamental of Physics 2 and Electricity and Magnetism course shows the low mental ability of students in electric and magnetic concept. There is the tendency of wrong concept and misconception. Meanwhile, there is no learning activity that can solve that problem in that previous research. It really causes apprehension considering that the students are the physics teacher candidates who will teach those concepts to their students. Thus, to improve physics teacher candidates' mental model in electric and magnetic material, it is necessary to design a course program that can train the students to solve the problems systematically by using hands-on and mind on activities, getting used to solve the problems, increasing learning experiences, and using the energy as minimum as possible in accessing and organizing their cognitive elements.

\section{METHODS}

This research employs 3D (define, design, develop) model of research and development (R \& D) method [12]. The first step is to define a step that investigates the students' mental model and MMA description (profile) in electric and magnetic concept (as in the previous research) [11], analysis of GBPP/SAP document (courses/material program document), and test items. The next step is to design to a step to make course program draft. It consists of RPP (lesson plans), LKM (student worksheet), $P D$ (lecturer's guide) and problem-solving test related to the material that will be investigated. Then, those course program drafts are validated by five experts (three supervisors and two independent raters) and piloted to 33 fourth semester students who took Electricity \& Magnetism course temporary.

The success indicators of this program are $75 \%$ extremely agree and agree on responses from the students, the improvement of a mental model, MMA, and problem-solving score. The instruments used to collect the data are students' and lecturers' response, electric and magnetic problem-solving test. There are three methods in the problem-solving test: traditional test (paper and pencil test), thinking aloud, and semi-structured interview to explore the consistency of students' answers particularly in determining mental model and MMA.

\section{RESUltS AND DisCUSSION}

The model and course manuals were tested to fourthsemester students taking Electricity \& Magnetism course. In this stage, the test used one group posttest design that provides a mental model level, MMA, and a problem-solving score of each student as shown in Table I.
TABLE I. THE RECAPITULATION OF MM, MMA, AND PS SCORE RESULT ON ELECTRIC AND MAGNETIC MATERIAL

\begin{tabular}{|c|c|c|c|}
\hline \multirow{2}{*}{\multicolumn{2}{|c|}{ Measured Aspects }} & \multicolumn{2}{|c|}{$\begin{array}{c}\text { Material/Number of Students } \\
(\%)\end{array}$} \\
\hline & & \multirow{2}{*}{$\begin{array}{l}\text { Electric } \\
10 \\
\end{array}$} & \multirow{2}{*}{$\begin{array}{c}\text { Magnetic } \\
15 \\
\end{array}$} \\
\hline MMLevel & $\mathrm{NC}(\%)$ & & \\
\hline & Level $1(\%)$ & 59 & 43 \\
\hline & Level $2(\%)$ & 25 & 29 \\
\hline & Level $3(\%)$ & 6 & 14 \\
\hline \multirow{4}{*}{$\begin{array}{l}\text { MMA } \\
\text { Category }\end{array}$} & Blank (\%) & 10 & 15 \\
\hline & L-MMA (\%) & 61 & 29 \\
\hline & M-MMA $(\%)$ & 21 & 38 \\
\hline & H-MMA (\%) & 8 & 19 \\
\hline \multicolumn{2}{|c|}{ PSScore $\geq 7$} & 16 & 41 \\
\hline
\end{tabular}

On the other hand, students' response towards $L K M$ shows that $26 \%$ of students are Extremely Agree and $61 \%$ of them are Agree. Lectures' response toward course program set are: evaluation manual's general criteria and the concept are Good, 56.3\% Extremely Agree and $43.7 \%$ Agree with RPP, 78.3\% Extremely Agree and $21.7 \%$ Agree with $P D$, and $52,4 \%$ Extremely Agree and 47,6\% Agree with $L K M$.

\section{A. The Characteristic of Program Developed}

Course program developed refers to problem-solving experiment-based course program from Ref. [13] that presents contextual rich problems in cooperative group problem-solving laboratory lecturing, and predict, observe, explain (POE) strategy [1], [6], [14]. Considering the characteristic of the expected mental model (level 3) and H-MMA (high mental modeling ability) category, problem-solving course model developed by Ref. [15] was adapted to the initial model design. The phases as the course stages are as below:

Phase 1 Students' orientation toward the problem. At this phase, lecturer informs the purpose and the competence that will be achieved through the learning process. Lecturers also conduct a perception, motivates the students to focus on the problem and present the problem.

Phase 2 Organizing the students to learn. Lecturer manages the students to work in small groups, gives $L K M$ to the students as the guidance in solving the problem and prepares the experiment equipment.

Phase 3 Guiding individual and group problem-solvingbased exploration. It is the main activity of learning process. In this phase, the students are trained to do problem-solving through experiment and get used to constructing mental model and MMA during the problem-solving process. Lecturer's activities at this phase are guiding the students in solving the problems through lecturer's guide $(P D)$, asking the students to solve the problems by doing these experiment stages: analyzing the problem and making prediction (prediction); designing the solution and observing (observe): designing the equipment (equipment), measuring (measurement), analyzing the data based on relevant concept (analysis), evaluating problemsolving process; and concluding (conclusion); explaining (explain) (in the form of figure, table, graph, or other representation) and comparing observation and prediction result.

Phase 4 Explaining and presenting experiment result. Lecturer's activities at this phase are facilitating each group to 
be able to elaborate their experiment result, communicating group experiment result, and guiding the students to discuss and inquire the result of the problem-solving process.

Phase 5 Enrichment and learning feedback. The last phase is giving correction and enrichment of concept based on $P D$, concluding the lesson with the students and facilitating learning follow-up through structured tasks.

\section{TABLE II. PROBLEM-SOLVING EXPERIMENT-BASED LEARNING} PHASES TO IMPROVE MM AND MMA

\begin{tabular}{|c|c|}
\hline Learning Phases & Lecturer's Activities \\
\hline $\begin{array}{l}\text { Phase } 1 \\
\text { Students orientation to } \\
\text { learn }\end{array}$ & $\begin{array}{l}\text { Presenting learning objective and competence } \\
\text { - Doing a perception } \\
\text { Motivating the students to focus on material } \\
\text { Organizing students into small groups }\end{array}$ \\
\hline $\begin{array}{l}\text { Phase } 2 \\
\text { Students orientation } \\
\text { toward the problem }\end{array}$ & $\begin{array}{l}\text { Presenting the problem } \\
\text { Giving } L K M \text { to the students as the guidance } \\
\text { in solving the problem } \\
\text { Preparing experiment equipment }\end{array}$ \\
\hline $\begin{array}{l}\text { Phase } 3 \\
\text { Guiding students to do } \\
\text { pre-experiment } \\
\text { discussion } \\
\text { (brainstorming) }\end{array}$ & $\begin{array}{l}\text { Asking the students to mention relevant } \\
\text { concepts related to the problem that will be } \\
\text { solved } \\
\text { Asking the students to mention the } \\
\text { connection (link) between those concepts } \\
\text { Asking the students to make the prediction of } \\
\text { problem-solving } \\
\text { Asking the students to design problem- } \\
\text { solving through an experiment with the } \\
\text { guidance of. } \\
\text { Guiding the students in designing problem- } \\
\text { solving }\end{array}$ \\
\hline $\begin{array}{l}\text { Phase } 4 \\
\text { Guiding individual and } \\
\text { group problem-solving- } \\
\text { based experiment }\end{array}$ & $\begin{array}{l}\text { Guiding the students to do experiment based } \\
\text { on the design that has been decided by the } \\
\text { group } \\
\text { Guiding the students in measuring } \\
\text { Guiding the students in analyzing the data by } \\
\text { referring to the relevant concept } \\
\text { Guiding the students to make explanation (in } \\
\text { the form of figure, table, graph, or other } \\
\text { representation) by comparing the observation } \\
\text { and prediction result } \\
\text { Guiding the students in checking experiment } \\
\text { process and making conclusion }\end{array}$ \\
\hline $\begin{array}{l}\text { Phase } 5 \\
\text { Evaluating problem- } \\
\text { solving result }\end{array}$ & $\begin{array}{l}\text { Facilitating each group to collect suggestion } \\
\text { or response to problem-solving process } \\
\text { result from other groups. } \\
\text { Guiding the students to discuss the result of the } \\
\text { problem-solving process. }\end{array}$ \\
\hline $\begin{array}{l}\text { Phase } 6 \\
\text { Enrichment and follow- } \\
\text { up }\end{array}$ & $\begin{array}{l}\text { - Giving evaluation and enrichment based on } \\
P D \text {. } \\
\text { - Summarizing. } \\
\text { - Facilitating learning follow-up by giving } \\
\text { structured tasks. }\end{array}$ \\
\hline
\end{tabular}

The result of the model application shows the increase of mental model, MMA, and problem-solving ability. There is an improvement of the mental model (see table 1) at level 2 from $25 \%$ to $29 \%$ and at level 3 from $6 \%$ to $14 \%$. This level should be taken into account because it describes students' ability in constructing a good mental model. The increase of MMA can be verified from the percentage of students who are in H-MMA criteria rises from $8.5 \%$ to $18.5 \%$. The improvement of problem-solving ability is proved by the rise of the students who get PS score $\geq 7$ from $16 \%$ to $41 \%$. Researcher compares the result in the electric and magnetic material because in testdrive the materials are discussed sequentially started with the electric material.

However, the reflections resulting from the expert who is an observer of learning process stated that the students still hesitate in connecting the concepts used to solve the problem. They focus only on one concept in problem-solving. A particular stage is needed to guide the students to discuss in groups before carrying out the experiment. Pre-experiment activities include exploring the concepts related to problem context to make a prediction and designing experiment procedures. This validation result of the expert was discussed and then the stages are agreed to be adjusted as below: Phase 1 Students orientation to learn; Phase 2 Students orientation toward the problem; Phase 3 Guiding students to do preexperiment discussion (brainstorming); Phase 4 Guiding individual and group problem-solving-based experiment; Phase 5 Evaluating problem-solving result; Phase 6 Enrichment and follow-up. These are the revised learning process that will be used in implementation (disseminate stage) and included in program manuals.

\section{B. The Characteristic of Course Manuals}

Students' worksheet $(L K M)$ is one of course manuals addressed to the students. It is adapted from model Ref. [16] consists of topic; real-world problem; daily life problem; experiment questions: questions that can be used by the students as the guidance to decide the focus of problem; experiment equipment: it is flexible, depend on the experiment design created by the students; prediction question: as the guidance for the students to make problem-solving prediction or solution; method question: as the guidance for the students to decide relevant concepts, connection between concepts, the units that will be measured and the method to measure it when doing the experiment; exploration: students do brainstorming to decide the possible methods (alternative solution) that can be used to solve the problem up to designing experiment procedure; measurement: students do experiment based on the procedure that has been made and makes the observation table if needed; analysis and explanation: consist of questions about experiment result and comparing it with the prediction; evaluation: as the guidance for the students to recheck every problem-solving step; conclusion: consist of questions that will direct the students to make conclusion. The topic presented in this problem-solving consists of seven topics: an electric charge, a combination of a capacitor, a combination of switches and lights, RC circuit, voltmeter, EMF induction, and generator.

Lecturer's guide $(P D)$ is a manual for lectures in guiding students' problem-solving process and it is meant for the lecturers, not the students. $P D$ includes the possible answers given by students when answering each question in $L K M$. Therefore, structures and questions found in $L K M$ can be seen in $P D$ as well.

Evaluation instrument or learning outcome assessment is developed based on a real-world problem from Ref. [13] in the book entitled Cooperative Group Problem-solving in Physics. Problem-solving is a rich problem in which the student as a problem solver is required to solve the contextual problem 
using some relevant concepts. Students should have problem analysis ability, link concepts based on context, make an analogy, and explain it by using appropriate representation [17]. Electronic and magnetic problem-solving $(P S)$ test used is different with a common essay test, specifically in test instruction. It states: "Kerjakan soal-soal berikut ini dengan cara memberikan jawaban berdasarkan pengetahuan anda. Tulislah dengan jelas berikut sketsa atau gambar sebagai ilustrasi semua yang terpikirkan oleh anda ketika menjawab soal tersebut pada lembar jawaban!" (Answer the questions below based on your knowledge. Write the answer clearly and provide sketch or figure as the illustration of all things that come to your mind when answering the questions). It is intended to give researcher access to students' mental model as the substitution of thinking aloud particularly in the classical test.

Students also give very positive response toward $L K M$ in which $87.5 \%$ students agree and extremely agree of its usage. It is supported by the good average score given based on lecturers' observation and judgment on course manuals testdrive.

\section{CONCLUSIONS}

Document analysis result of $G B P P / S A P$, and experiment manual shows that all of them are traditional, the learning process still consists of lecturing-exercise-task. Practicum manual is still cookbook and dominantly separated and unrelated with the material being learned. Students test items are rarely used problem-solving test. Therefore, this problemsolving experiment-based course program can be implemented to improve the mental model and mental-modeling ability so the students will be able to solve the problem correctly and appropriately.

This research result indicates that physics lecturers and students should consider several points:

- The relevance between concepts in physics. Solving the problems, particularly related to real-world problems needs the relevance of physics concepts. It is not related to one concept has been learned only. The lecturer as the facilitators should consider this thing.

- It would be better for the lecturer to identify students' prior knowledge. Without sufficient knowledge, students cannot build their mental model well. The ability to construct a mental model and apply it in problem-solving process will affect the success in problem-solving experiment-based course significantly.

\section{ACKNOWLEDGMENTS}

We wish to thank Jusman Mansyur, Komang Werdhiana, and Andhy Setiawan for them advise and contributions to the study. We also like to thank A. Rusli for his advice and contributions to the study and constructive comments on the manuscript.

\section{REFERENCES}

[1] C. Y. Wang, "The Role of Mental-Modeling Ability, Content Knowledge, and Mental Models in General Chemistry Students' Understanding about Molecular Polarity," Ph.D. Dissertation, University of Missouri, Columbia, 2007.

[2] J. Mansyur, "Kajian fenomenografi aspek-aspek model mental Subyek lintas level akademik dalam Problem-solving konsep dasar mekanika," Dr. Dissertation, Science Education Department SPs UPI, Bandung,2010.

[3] E. D. Corpuz, and N. S. Rebello. Investigating students' mental models and knowledge construction of microscopic friction. II. implications for curriculum design and development. Physics Review Special Topics PER. 7, (2), p. 020103-1 - 020103-8, 2011.

[4] N. Didiș, A. Eryilmaz, and Ş. Erkoç. Investigation students' mental models about the quantization of light, energy, and angular momentum. Physical review special topics-Physics education research. Vol. 10, 020127, p.020127-1 - 020127-28, 2014.

[5] S. Vosniadou, I. Skopeliti, and K. Ikospentaki. Modes of Knowing and Ways of Reasoning in Elementary Astronomy. Journal Cognitive Development. 19, 203-222, 2004.

[6] N. Jansoon, R.K. Coll, and E. Somsook. Understanding mental models of dilution in Thai students. International Journal of Environmental \& Science Education, 4, (2), 147-168, 2009.

[7] B. Korsunsky. Ready, SET, Go! A research-Based Approach to Problem-solving. Jurnal The Physics Teacher, 42, 493-497, 2004.

[8] T. Gök and I. Silay. The Effects of Problem Solving Strategies on Students' Achievement, Attitude, and Motivation. Am. J. Phys. Educ. Vol. 4, No.1, Jan. 2010.

[9] D.H. Putri and M. Sutarno. Model Kegiatan Laboratorium Berbasis Problem Solving pada Pembelajaran Gelombang Optik untuk Meningkatkan Keterampilan Proses Sains Mahasiswa. Jurnal Exacta, Vol. X. No 2. December 2012.

[10] L.N. Walsh, R.G. Howard, and B. Bowe. Phenomenographic Study of Students' problem-solving approaches in physics. Journal Physics Review Special Topics PER. 3, 020108, 2007.

[11] Supriyatman, A. Suhandi, A. Rusli, and D. Rusdiana. The Profile of Student Physics Education Mental Model in Electricity and Magnetism Concepts Using Problem-solving Test. International Journal of Science and Research, 3, 8, 2093-2097, August 2014

[12] W.R. Borg, \&M.D. Gall. "Educational research (4th ed.)."New York: Longman, 1983

[13] K. Heller and P. Heller. "Problem-Solving Labs. Introductory Physics Ist Mechanics. Cooperative Group problem-solving in physics." Research Report, Minossota: University of Minnesota, 1999.

[14] H. Khanthavy, \&C. Yuenyong. Examining Lao Student's Mental Model of Force and Motion. European Journal of Social Sciences, 35, (3), 273283, 2012.

[15] M.P. Simanjuntak. "Pengembangan Model Pembelajaran Fisika Dasar Berbasis Problem-solving untuk meningkatkan Kemampuan Metakognisi dan Pemahaman Konsep Mahasiswa." Dr. Dissertation of Science Education Department SPs UPI, Bandung, 2012.

[16] P. Heller, R. Keith, and S. Anderson. Teaching problem-solving through cooperative grouping. Part 1: Group versus individual problem-solving. American Journal Physics (Am.J.Phys), 60, (7), 627-636, 1992.

[17] J.K. Gilbert,M. Reiner, and M. Nakhleh. "Models and Modeling in Science Education, visualization: theory and practice in science education (Vol. 3).”UK: Springer, 2007. 